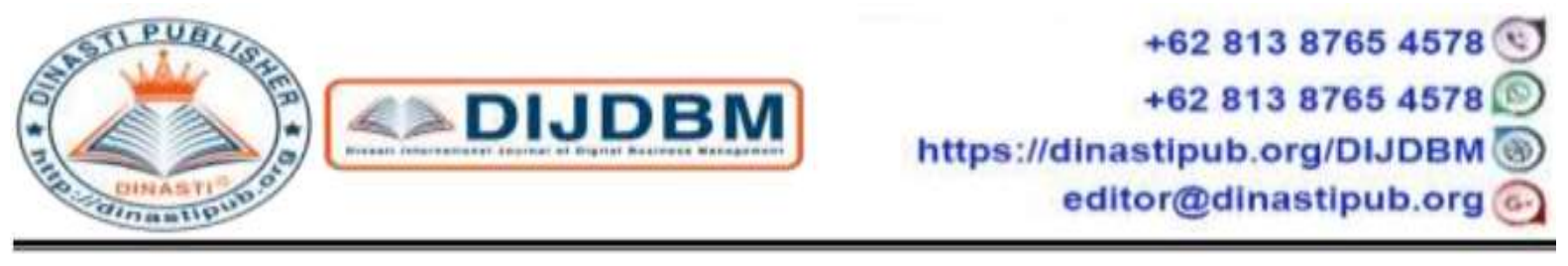

\title{
ANALYSIS OF IMPLEMENTATION OF SERVICE TO TAX MANDATORY IN PRATAMA TAX SERVICE OFFICE
}

\author{
${ }^{1}$ Agus Bandiyono, ${ }^{2}$ Rama Daneshwara \\ ${ }^{1)}$ Politeknik Keuangan Negara STAN, Indonesia \\ ${ }^{2)}$ Politeknik Keuangan Negara STAN, Indonesia
}

\section{ARTICLE}

\section{INFORMATION}

Received: 25 December 2019

Revised: 29 December 2019

Issued: 31 December 2019

Corresponding author: agus.bandiyono@gmail.com

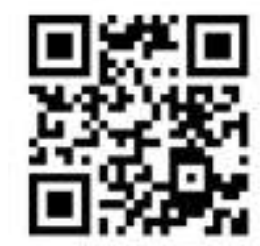

DOI:10.31933/DIJDBM
Abstract: This research aims to analyze the implementation of the service STO Jakarta Kelapa Gading according to the Circular of the Director-General of Tax No. SE - 84 / PJ / 2011 and SE - 09 / PJ / 2013, and within six components of the assessment Pilot KPP. The research method used to obtain and analyze data that can support this writing is a qualitative method through interviews and document collection through library research. The implementation of excellent service is an obligation of the KPP as a public service provider. To carry out performance evaluations and give awards to offices that have performed excellent service according to existing regulations, an assessment was held to obtain a pilot KPP title held by the Ministry of Finance Assessment Team. This assessment is regulated in Decree of the Minister of Finance of the Republic of Indonesia Number 128 / KMK.01 / 2013 concerning Guidelines for Evaluation of Pilot Service Offices in the Ministry of Finance and Decree of the Director-General of Tax Number KEP-161 / PJ / 2015 concerning Guidelines for Evaluation of Pilot Services Offices at Regional Office Level Directorate General of Taxes. Jakarta Kelapa Gading KPP is the first KPP Pilot Model in the North Jakarta area. Therefore following the implementation of existing services so that the KPP can get a pilot KPP title.

Keywords: Public sector management, Taxation, Public services, Tax Administration, State Finance 


\section{INTRODUCTION}

The Tax Service Office (KPP) is one of the offices under the Directorate General of Tax (DJP) agency that carries out public service duties in the field of taxation in Indonesia (Bandiyono \& Sadry, 2018). As a public service provider, KPP is always required to provide the best service for the community (Bandiyono \& Pratama, 2019). In carrying out its duties and functions, KPP always upholds the values of the Ministry of Finance including integrity, professionalism, synergy, service, and perfection (Bandiyono \& Aryani, 2019). In this study, the writer will focus more on just two values namely service and perfection. The value of "service" includes serving oriented to stakeholder satisfaction and being proactive and responsive. The value of "perfection" includes making continuous improvements and developing innovation and creativity. To support the value of "service" and "perfection", each KPP is expected to always make improvements and improve the quality of service to the community because it is one of the important and strategic tasks of each government agency (Bandiyono \& Simbolon, 2018)

Every office in the environment DGT is expected to be able to carry out excellent service under Circular of the Director-General of Taxes Number SE - 84 / PJ / 2011 (Bandiyono \& Rahmawati, 2018). To carry out performance evaluations and give awards to offices that have provided excellent service, an evaluation is held annually. The assessment activities within the Ministry of Finance are called the Pilot Service Office (KPPc) assessment (Bandiyono, 2017). This assessment is carried out by the Ministry-Level Assessment Team and the Echelon I Organizational Unit Level Assessment Team. Each office within the Directorate General of Tax (DGT) that has a good assessment of services following the applicable regulatory guidelines will receive the title of KPP (Bandiyono \& Chaerul), 2018).

With an objective, transparent and accountable assessment, it is expected to be able to provide stimulus and motivation for each service office to provide excellent service following existing laws and regulations. (Asriyani \& Bandiyono, 2019). Good service delivery according to existing regulations is expected to provide satisfaction to the community (Bandiyono, 2017). There are several things that the author will review about the implementation of the KPP, for example, service standards, service procedures, service facilities and infrastructure, complaint handling and so on (Bandiyono, 2017). This study aims to analyze the implementation of Jakarta Kelapa Gading KPP services according to the Director-General of Tax Circular No. SE - 84 / PJ / 2011 and SE - 09 / PJ / 2013 and in the 6 components of the pilot KPP assessment.

The office that was the place of observation was the Pratama Jakarta Kelapa Gading Tax Service Office (KPP). This office is the first winner in the evaluation of a pilot service office in the North Jakarta area held by the Ministry of Finance Assessment Team in 2015. The author will analyze the implementation of the KPP Pratama Jakarta Kelapa Gading service based on the Director-General of Tax Circular Letter Number SE - 84 / PJ / 2011 and SE - 09 / PJ / 2013 and the actual implementation in the field in terms of the author's observation and the perspective of the taxpayer. As well as reviewing the KPP services in several components of the pilot KPP assessment, including:

1. vision and mission, service motto of service

2. standards and information on service 
3. systems, mechanisms, and procedures for services

4. human resource

5. facilities and infrastructure for

6. handling complaints.

\section{LITERATURE REVIEW}

\section{Public Services}

Based on Law Number 25 of 2009 concerning Public Services, it is understood that public services are activities or a series of activities in the framework of meeting service needs under statutory regulations for every citizen and resident of goods, services, and/or administrative services provided by public service providers.

The scope of public services according to Law Number 25 the Year 2009 Article 5 paragraph 4, namely services to public services as referred to in paragraph (1) include:

a. the provision of public services by government agencies which part or all of the funds come from the state revenue and expenditure budget and / or regional revenue and expenditure budget.

b. the provision of public services by a business entity whose capital is partly or wholly sourced from state assets and / or separated regional assets, and

c. the provision of public services whose financing does not originate from the state budget or regional income and expenditure budget or business entity whose capital is partly or wholly sourced from state assets and/or separated regional assets, but availability becomes the state mission stipulated in the legislation.

Organizers of Public Services Based on the Law "Public service providers or Organizers are any state administering institutions, corporations, independent institutions established under the law for public service activities, and other legal entities formed solely for public service activities (Bandiyono \& Ustadnia, 2018).

Excellent service according to the Director-General of Tax Circular Number SE - 84 / PJ / 2011.

One of the strategic objectives of the Directorate General of Tax (DGT) is to increase the satisfaction of taxpayers and all stakeholder's taxation to realize a high level of public trust in taxation services (Bandiyono, 2016). This is in line with the mandate of Law Number 25 the Year 2009 regarding Public Services and in the context of increasing DGT performance achievements. One effort to achieve a high level of satisfaction with taxation services is to improve the quality of services to taxpayers (Bandiyono, A., \& Murwaningsari, 2019). To improve the quality of service to taxpayers to create excellent service, it is necessary to build a service mindset as part of the application of the Ministry of Finance's values of professionalism and service in all DGT levels (Bandiyono, 2018).

According to the Director-General of Tax Circular Number SE - 84 / PJ / 2011 regarding excellent service, there are several criteria regarding excellent service, namely:

a. Integrated Service Place service standards.

The service time at TPT is 08.00 to 16.00 local time. The time difference between work hours and service hours is used to prepare for providing services (morning prayers and spirits, briefing, spatial planning, and administration as well as preparation for TPT officers) 
and closing service preparations (evaluating services performed, tidying and completing service administration at that day). During recess, the service is still provided by taking turns regulating the resting officers and increasing the number of officers if the Integrated Service Place has a long queue.

b. Facility standard.

A minimum list of facilities and infrastructure according to standards is in Appendix II. TPT is a public area within the Tax Office. Tax Office has two types of areas, namely:

a) General Area( PublicArea).

Taxpayers may freely enter and exit without using certain attributes to get good tax services following service quality standards.

b) Restricted Area.

Unauthorized parties are not permitted to freely enter and exit the area to obtain taxation services.

c) Human resource standards.

Employees who deal directly with taxpayers must maintain good manners and behavior, be friendly, responsive, careful and fast, and do not complicate service.

\section{Pilot Tax Service Office.}

To evaluate the performance of public services and give awards to service offices that have performed excellent service, an assessment is needed annually (Bandiyono \& Augustine, 2019). Performance evaluation by conducting an assessment is carried out to find an objective picture of performance from the service office and providing stimulus or motivation in the form of awards is a strategic step in encouraging efforts to improve and improve the quality of public services (Bandiyono \& Andri, 2012). The assessment is carried out by taking into account the improvement of excellent service in the framework of fulfilling public services according to the DGT strategic plan, other criteria and indicators stipulated in the Decree of the Director-General of KEP-161 / PJ / 2015 and by observing the results of evaluation of Kanwil Level Regional Service / KPPc evaluation in the year previous.

Regional Office KPPc evaluation organization is the Regional Office Assessment Team. The Regional Office Assessment Team is tasked with carrying out the preparation, formulation, and evaluation of the performance of public services at the service offices in the working area (Bandiyono \& Al Fajar, 2018).

The Regional Office KPPc assessment instrument is in the form of the Regional Office KPPc Assessment Form as contained in Appendix II of the Decree of the DirectorGeneral of Tax Number KEP-161 / PJ / 2015 concerning Guidelines for Evaluation of Pilot Service Offices at the Regional Office Level at the Directorate General of Taxes. Regional Office Level Assessment Forms used by the Regional Office Assessment Team include the following evaluation components (Bandiyono \& Akhmadi, 2018):

1) Vision, Mission, Information, Standards, Service Motto and Service Plans for KPP.

This component is related to the vision, mission, information, standards, motto, and promise of KPP services that are relevant to the service. Vision, mission, information, standards, motto and service promise must also be socialized and implemented properly.

2) Ministry of Finance Values. 
This component relates to the Ministry of Finance values that have been launched that must be truly understood, realized and implemented by all DGT employees including employees in the service department.

3) Evaluation and compliance with Standard Operating Procedures (SOP) Services.

This component relates to the employee's concern to comply with and provide services to taxpayers under SOP and to try to be more efficient.

4) Human Resources (HR).

This component relates to employee professionalism which includes attitudes and behaviors, skills, sensitivity, and discipline.

5) Service office innovation.

This component relates to the concern of leaders and employees in developing innovations in providing services, human resource development and relations with the prevention of corruption.

6) Handling of Taxpayer Complaints and complaints.

This component is related to the concern of leaders and employees to anticipate the complaints and complaints of taxpayers, especially towards service satisfaction.

7) Availability and Optimization of Service Infrastructure Facilities.

This component relates to the availability and use of service facilities and infrastructure.

8) Community Satisfaction Index (IKM).

This component contains statements of satisfaction of taxpayers in various forms based on the latest survey conducted by the Directorate of Public Service and Public Relations.

9) Leadership Concern.

This component includes leadership concern for services to taxpayers.

10) Taxpayer compliance level.

This component assesses the increase in taxpayer compliance from time to time.

11) Tax Revenue Performance.

This component assesses the achievement of tax revenue targets from time to time.

12) Public Service Information System.

This component relates to the service information management system, the form/form of information delivery, and the level of information disclosure to service users.

13) Archive Management.

This component relates to the process of managing archives, ease of finding files, tidiness of file space and security in file space.

14) Productivity in Achieving Service Targets.

This component relates to the determination of service targets and the level of achievement of these targets.

15) Achievements that have been achieved in the past 3 years.

This component relates to the achievements of service offices in the past 3 years, both individual (employee) or office and local/regional or national.

\section{RESEARCH METHODS}

The research method used to obtain and analyze data that can support this writing is a qualitative method through interviews and document collection through library research.

1. Literature Study Methods. 
The method of literature study is carried out by studying several literature to obtain a theoretical basis regarding the pilot service office. The intended literature is in the form of taxation laws and implementing regulations, books, articles, and DGT pages.

2. Field Study Methods.

The field study method was carried out to obtain data that described the actual conditions in the field. Data collection is carried out by reviewing documents related to the assessment of the pilot service office and services at the office. Besides, data collection can be done by interviewing and distributing questions through a questionnaire to the parties directly related

Following the Regulation of the Minister of Finance of the Republic of Indonesia (PMK) Number: 62 / PMK.01 / 2009 dated April 1, 2009, concerning Organization and Work Procedures of the Vertical Institution of the Directorate General Tax, KPP Pratama Jakarta Kelapa Gading has organized a modern administration system.

In evaluating and analyzing the performance of KPP Pratama Jakarta Kelapa Gading during the period of 2015, the following is a brief explanation:

\section{Optimal tax revenue.}

a. Achievement of tax revenue targets.

Realization of revenue in 2015 amounted to Rp2,693,418,944,067.00 and the 2014 target that had to be achieved was Rp3,456,024,901,998.00 so that it could be realized with an achievement level of $77.93 \%$. This shows that the achievement of tax revenues in 2015 still could not meet the 2015 Main Performance Index (KPI) target of 100\%. The obstacles faced in achieving revenue in 2015 are due to the 2015 target which grew $29 \%$ from the previous year in addition to falling import transactions and low demand for imported goods.

b. Achieve the target of receiving extra effort.

Realization of the receipt of extra effort amounted to Rp620,090,882,056.00 and the 2015 target to be achieved was Rp1,274,977,132,476.00 so that it could be realized with an achievement level of $48.64 \%$. This shows that the achievement of receiving extra effort in 2015 still did not meet the 2015 IKU target of $100 \%$. The obstacles in achieving extra effort include the absence of valid data with large material to support reception.

Activities that have been carried out to achieve the tax revenue target and achieve the revenue target extra effort are the realization of PPh, VAT and PPnBM tax revenue and other taxes through:

1) Exploration of potential profiles / surgical taxpayers (WP) determinants of revenue

2) Supervision of future payments

3) Excavation of potential WP Treasurers

4) Excavation the potential for WP of Certain Individual Entrepreneurs (OPPT) and WP based on PP 46

5) Excavation of transaction-based potential (Quick Yielding), and

6) Utilization of data on alerts, PIB and PEB, OPDP and data on the DGT portal.

\section{Public Service Fulfillment.}

The indicators seen are the achievement of e-Fin and e-Filing. The realization of e-Fin and E-Filing in 2015 amounted to 5,169 WP and the 2015 target that must be achieved is $4,375 \mathrm{WP}$ so that it can be realized with an achievement level of $118.15 \%$. Thus the achievement is above the 2015 IKU target of $100 \%$. 
The activity carried out is looking for company data with a lot of employees as well as conducting counseling/dissemination of SPT submission through E-Filing.

\section{High level of taxpayer compliance.}

The realization of the Annual Income Tax Return submitted by the Taxpayers in 2015 was $28,801 \mathrm{WP}$ of the target of 39,725 registered WP so that the formal compliance level of WP was achieved at $72.5 \%$. This shows that the WP compliance level is the same as the IKU 2015 target of $72.50 \%$. The activities that have been carried out are issuing warnings/appeals / tax bills to WP / PKP that do not or have not submitted Annual Income Tax Returns, provide tax socialization regarding the implementation of rights and WP / PKP obligations, especially new WP / PKP.

\section{Increasing the effectiveness of services and counseling.}

The number of tax service complaints that were followed up during 2015 was $10 \mathrm{WP}$ of the total tax service complaints amounting to $10 \mathrm{WP}$ so that the target of the taxation service complaint follow-up was $100 \%$ or exceeding the 2015 IKU target of $70 \%$.

\section{Increased Inspection Effectiveness.}

a. Realization of Audit Completion.

The number of inspections completed in 2015 was 192 LPP with a conversion value of 98.20 from the completion target of 205.09 or $47.88 \%$ achievement rate was still below the target of the Audit Completion IKU of $80 \%$

b. Examination Completed on Time.

The number of examinations completed on time in 2015 was 77 LPP out of the total completed 192 LPP or achieved $37.50 \%$. Thus the level of achievement of timely inspection is still below the 2015 IKU target of $70 \%$. Steps taken to improve the functional performance of the examiner are by:

1) Supervising the completion of audit arrears with priority auditing for the 2011 tax year in connection with the expiration date.

2) Complete inspection on time.

\section{Competitive HR.}

a. Timely Performance Assessment.

The number of Performance Contracts that were signed on time for 2015 was 92 employees from the number of performance contracts that should have been signed by 92 people or a $100 \%$ achievement rate. Thus, the level of achievement is the same as the 2015 target of $100 \%$.

b. Employees Who Meet Jamlat Standards.

The number of employees who meet the Jamlat standard is 92 employees from all employees as many as 91 employees or the achievement level of $98.91 \%$ so that the achievement level exceeds the 2015 IKU target of $50 \%$.

The author will observe how the service at Jakarta Kelapa Gading KPP. The matter to be reviewed is whether the KPP has implemented excellent service following the Circular of the Director-General of Tax Number SE - 84 / PJ / 2011 regarding excellent service and SE 09 / PJ / 2013 regarding guidelines for excellent service. Taxable Service Offices that have carried out services well will be carried out following an assessment within the scope of the Directorate General of Taxes. Therefore, the author will also review how the service at this KPP according to several components which become the assessment instruments of the Pilot 
KPP based on the Decree of the Minister of Finance of the Republic of Indonesia Number 128 / KMK.01 / 2013 concerning Guidelines for Evaluation of Pilot Service Offices within the Ministry of Finance and Director General Decree Tax Number KEP-161 / PJ / 2015 concerning Guidelines for Evaluating Pilot Services Office at the Regional Office Level at the Directorate General of Taxes.

\section{FINDINGS AND DISCUSSION}

Review of the implementation of KPP Pratama Jakarta Kelapa Gading service according to Circular of the Director-General of Taxes Number SE - 84 / PJ / 2011 and SE - 09 / PJ / 2013.

a. The author's observational aspect.

Based on the writer's observation at KPP Pratama Jakarta Kelapa Gading on Friday, June 10, 2016, the service, especially at the Integrated Service Place (TPT), starts at 08.00 WIB. Previously, it was preceded by a group prayer led by the voice from the loudspeakers throughout the office. Following the Circular of the Director-General of Tax Number SE - 84 / PJ / 2011 regarding excellent service, each officer is in their respective position, namely the TPT officer is at the ticket window, the security officer is at the security guard's desk, and the officer is helpdesk ready at the place.

The circular also explained that the office area is divided into 2 (two), namely the public area (public area) and restricted area(Bandiyono, A., \& Andiani, 2017). In general areas, taxpayers may freely enter and exit without using certain attributes to get good tax services following service quality standards. In a restricted area, unauthorized parties are not permitted to freely enter and exit the area to obtain taxation services. The public areas in this office include the first floor where there is an Integrated Service Place (TPT) and Service Section. The restricted area covers 3 floors above where there are Extensification Sections, Billing Sections, General Subsections, etc. Taxpayers need to fill out a guest book, leave their $\mathrm{KTP}$, and wear the guest card that has been provided to be able to access the restricted area. In the circular also that employees are required to maintain manners and behavior, friendly, responsive, careful and fast, and does not complicate service. Every taxpayer who came was welcomed, questioned about his needs and politely invited to take a queue number by security officers. Employees at the counter are ready with neat clothes and complete attributes such as employee identity cards in breast pockets. Taxpayers who have been called in queue numbers are welcomed by officers with greetings and smiles. After that, the officer provides services according to existing service standards.

To support the implementation of good service, KPP Pratama Jakarta Kelapa Gading has prepared all adequate facilities according to the writer's observation and under the facility, standards contained in the Director-General of Tax Circular No. SE - 09 / PJ / 2013 (Bandiyono \& Ahmad, 2018). The list of facilities in the office's services and how they are used is in Appendix II based on the facility standards contained in the circular. With the fulfillment of the appropriate facilities, it is expected to make Taxpayers and officers feel comfortable in the office.

b. The perspective of the taxpayer.

Objective observation must be viewed from various points of view. Therefore, the authors also made observations through the perspective of the Taxpayer as a service user of 
this KPP by using a questionnaire. Questionnaire with closed questions has been given to several taxpayers as a sample to find out how the opinion of taxpayers regarding the implementation of services at KPP Pratama Jakarta Kelapa Gading. The following table is the results of questionnaire data processing from 25 respondents who have been obtained by the author.

1) Ease of Service Procedures.

The following table answers Taxpayers about how to facilitate the service procedures at KPP Pratama Jakarta Kelapa Gading.

Table 1. Results of the questionnaire regarding the ease of service procedures

\begin{tabular}{|l|c|}
\hline \multicolumn{1}{|c|}{ Response } & Percentage \\
\hline Not easy & $0 \%$ \\
\hline Less easy & $28 \%$ \\
\hline Easy & $56 \%$ \\
\hline Very easy & $16 \%$ \\
\hline
\end{tabular}

Source: Results of questionnaire distribution

From table 1 we can see service procedures at KPP Pratama Jakarta Kelapa Gading deemed easy by most taxpayers with a percentage of $56 \%$ and $16 \%$ answered the service procedures are very easy. Another $28 \%$ of respondents consider the procedure to be less easy. All service procedures have been determined by regulations in the Directorate General of Taxes. Therefore, the making has been through various considerations to be effective and efficient at the time of its implementation. With a straightforward procedure will build a mindset positive on taxpayers so that they will carry out their tax obligations properly.

2) Discipline of officers in providing services.

The following table answers Taxpayers about how the level of discipline of officers in providing services at Jakarta Kelapa Gading KPP.

Table 2. Results of questionnaires for the level of discipline of officers in providing services

\begin{tabular}{|l|c|}
\hline \multicolumn{1}{|c|}{ response } & Percentage of \\
\hline Discipline & $0 \%$ \\
\hline Less discipline & $32 \%$ \\
\hline Discipline & $64 \%$ \\
\hline Very disciplined & $4 \%$ \\
\hline
\end{tabular}

Source: Results of distribution of questionnaires

From table 2 it appears that $64 \%$ of respondents assess officers are disciplined in providing services and $4 \%$ answered very disciplined. $32 \%$ of other respondents consider the level of discipline of officers is still lacking. In practice, every employee of the Directorate General of Taxes is required to have a disciplined attitude that reflects the values of the Ministry of Finance. A good employee image will be a benchmark of how the quality of service in this office.

3) Officer responsibilities in providing services.

The following table answers Taxpayers about how the responsibilities of officers in providing services at Jakarta Kelapa Gading KPP.

Table 3. Results of the questionnaire regarding the officer's responsibility in providing services

\begin{tabular}{|l|c|}
\hline \multicolumn{1}{|c|}{ Response } & Percent \\
\hline Irresponsible & $0 \%$ \\
\hline Less responsible for & $8 \%$ \\
\hline Responsible for & $84 \%$ \\
\hline
\end{tabular}




\begin{tabular}{|c|c|}
\hline It is responsible for & $8 \%$ \\
\hline
\end{tabular}

Source: Results of questionnaires

According to the Circular of the Director-General of Tax No. SE - 09 / PJ / 2013

regarding excellent service guidelines, every employee at KPP must be able to behave responsibly professionally. From the results of the processing of the Taxpayer questionnaire data, most of them have assessed that the service officers in the Jakarta Kelapa Gading KPP have been held accountable well. This will foster a sense of trust in taxpayers for existing services.

4) The ability of officers to provide services.

The following table answers Taxpayers about how the ability of officers in providing services at Jakarta Kelapa Gading KPP.

Table 4. Questionnaire results about the ability of officers to provide services

\begin{tabular}{|l|c|}
\hline \multicolumn{1}{|c|}{ Response } & Percentage \\
\hline Not able & $0 \%$ \\
\hline Poor able & $8 \%$ \\
\hline Able & $72 \%$ \\
\hline Very Able & $20 \%$ \\
\hline
\end{tabular}

Source: Results of questionnaire distribution

The ability of officers is oriented to the knowledge and expertise of the officer. In a Director General of Tax Circular Number SE - 09 / PJ / 2013 concerning guidelines for explicit prime services regarding general requirements and basic competencies for officers who work specifically in the KPP Services Section. In other words, the officers who serve Taxpayers must have the abilities required at the Directorate General of Taxes. From the table above, most Taxpayers have assessed that service officers at the Jakarta Kelapa Gading KPP are capable of carrying out their duties.

5) The level of speed of officers in providing services.

The following table answers Taxpayers about how the speed of officers in providing services at Jakarta Kelapa Gading KPP.

Table 5. Results of the questionnaire regarding the speed of the officer to provide services

\begin{tabular}{|l|c|}
\hline \multicolumn{1}{|c|}{ Response } & Percentage \\
\hline rapid & $8 \%$ \\
\hline less fast & $48 \%$ \\
\hline Faster & $44 \%$ \\
\hline Very fast & $0 \%$ \\
\hline
\end{tabular}

Source: Results of questionnaires

From the above data, we can see the state of nearly balanced between the opinions Taxpayers who said that the ministry KPP it's not fast enough. $48 \%$ of respondents thought that it was not fast enough and $44 \%$ of other respondents thought that the KPP service was fast enough. Most taxpayers still think that the services available are still not fast enough. Each type of service has its service standards that also regulate the completion period. Officers make these standards as a guide in serving taxpayers. But in the implementation in the field, several other indicators determine the time of completion of the service. Other indicators are for example the number of officers who have been reduced due to education and training or are currently receiving other assignments. This is a challenge for KPP to be able to provide satisfaction for the services they provide.

6) Courtesy and friendliness of officers in providing services. 
The following table answers Taxpayers about how the level of courtesy and friendliness of officers in providing services at this KPP.

Table 6. Questionnaire results about the courtesy and friendliness of officers in providing services

\begin{tabular}{|c|c|}
\hline Response & Percentage \\
\hline Not polite and friendly & $0 \%$ \\
\hline Less polite and friendly & $8 \%$ \\
\hline Polite and friendly & $76 \%$ \\
\hline Very polite and friendly & $16 \%$ \\
\hline
\end{tabular}

Source: Results of questionnaire distribution

7) Comfort at KPP Pratama Jakarta Kelapa Gading.

Comfort is one indicator for someone to feel satisfied in doing something. The following table answers Taxpayers about how comfort level in KPP Pratama Jakarta Kelapa Gading from the questionnaire that the author has shared.

Table 7. Questionnaire results about comfort at KPP Pratama Jakarta Kelapa Gading

\begin{tabular}{|l|c|}
\hline \multicolumn{1}{|c|}{ Response } & Percentage \\
\hline Uncomfortable & $0 \%$ \\
\hline Less comfortable & $16 \%$ \\
\hline Comfortable & $60 \%$ \\
\hline Very comfortable & $24 \%$ \\
\hline
\end{tabular}

Source: Results of questionnaire distribution

The level of comfort is assessed based on how the atmosphere and facilities are at KPP Pratama Jakarta Kelapa Gading. Completeness of facilities in this office services section can be seen in the table in Appendix II. The results of questionnaire data processing shows that the majority of taxpayers who are respondents feel comfortable in KPP Pratama Jakarta Kelapa Gading. 24\% of respondents gave the title of being very comfortable when in office space. Taxpayer's satisfaction is not only supported by how the process of implementing the service, but the place where he is also very influential.

Review of the implementation of KPP Pratama Jakarta Kelapa Gading services in 6 components of pilot KPP assessment.

Every Tax Service Office is always required to optimize services to increase the satisfaction of taxpayers by carrying out each task and function based on the existing regulations related to service standards. It is intended that the implementation of excellent service under the Director-General of Tax Circular Number SE - 84 / PJ / 2011. To carry out performance evaluations and give awards to offices that have provided excellent service, an evaluation is held annually. This assessment is regulated in Decree of the Minister of Finance of the Republic of Indonesia Number 128 / KMK.01 / 2013 concerning Guidelines for Evaluation of Pilot Service Offices in the Ministry of Finance and Decree of the DirectorGeneral of Tax Number KEP-161 / PJ / 2015 concerning Guidelines for Evaluation of Pilot Services Offices at Regional Office Level Directorate General of Taxes. In the assessment process, various components are used as assessment instruments. The following components are used as assessment instruments.

a. Vision and mission, and service motto.

b. Service standards and information about services.

c. Systems, mechanisms, and procedures.

d. Human Resources. 
e. Facilities and infrastructure.

f. The handling of complaints.

The author has made observations and several interviewing officers at the KPP Pratama Jakarta Kelapa Gading related to the implementation of services seen from several components and indicators of assessment.

a. Vision and mission, and service motto.

The assessment indicators for this component include:

1) Is there a KPP vision and mission?

2) Is the vision and mission relevant to the ministry?

3) Is there a service motto?

4) Is the service motto relevant to the service?

An organization must have a vision and mission of each following the purpose of the formation of the organization (Bandiyono, 2017). With this, an organization will have the same goal to be achieved by its members. Jakarta Pratama KPP Kelapa Gading is an organization that has its vision and mission and is different from other KPP but still refers to DGT's vision and mission with adjustments according to the conditions of the KPP. The service motto is a milestone of employee enthusiasm in carrying out their duties. The service motto of KPP Pratama Jakarta Kelapa Gading is "We always try to provide the best". KPP is a public service provider, so the service motto must be relevant to the services provided. In this office, the leadership always emphasizes that employees must know about the vision, mission and service motto. By knowing the vision, mission, and motto of service, all employees will know what steps to take and can be their motivation in working.

b. Service standards and information about services.

Standards are benchmarks used as a minimum guideline for service delivery and a reference for assessing service quality. Standards are things that must be done by each service provider. Service standards at this KPP refer to service standards set at the DGT. Information on KPP Pratama Jakarta Kelapa Gading service contains words that represent the service conditions at this KPP. Naturally, the information of one KPP with another KPP can be different because the challenges of each KPP are also different. The proclamation is like a lighter and needs human resources to activate it. With the application of standards and information published in the Jakarta Kelapa Gading KPP service, it is expected to gain the trust of the taxpayer.

c. Systems, mechanisms, and procedures.

As a state civil apparatus, the basis for employees in working in the regulations. Standard Operating Procedures are instructions for employees in working. (Bandiyono, 2017). Jakarta Kelapa Gading KPP in carrying out its services is guided by the Standard Operating Procedures (SOP) that have been regulated in the Directorate General of Taxes. All administrative activities already have SOPs and everything has been arranged in DGT completely. (Bandiyono \& Nugraha, 2018). However, this does not rule out the possibility that a KPP can make breakthroughs that do not conflict with the existing SOPs because they adhere to one of the Ministry of Finance's values of "perfection". This value demands to always make efforts to improve in all fields and develop innovation and creativity. KPP Pratama Jakarta Kelapa Gading has an innovation using e-KTP validation in making Taxpayer Identification Numbers (NPWP). In the regulation for making NPWP, it can be written using KTP or e-KTP. However, this KPP chose to implement NPWP making using eKTP. This aims to facilitate the validation and support of other government programs. When the officer enters the KTP number and it turns out the Taxpayer data is not registered, the officer will urge the Taxpayer to do the e-KTP recording or confirm to the village where the 
address of the Taxpayer. Confirmation needs to be done because the database is Jakarta Kelapa Gading KPPupdated every 6 months. (Bandiyono \& Listia, 2018). Besides, the KPP's advantage is to fully implement certain rules that other KPPs have not applied in their offices, for example giving a brief explanation to the Taxpayer when submitting an NPWP application. According to the Director-General of Tax Circular Number SE - 60 / PJ / 2013 when the Taxpayer submits a request in writing directly to the KPP or KP2KP, the Registration Officer provides a brief explanation of the rights and obligations of the Taxpayer, and the Taxpayer must sign a statement using the example format which is an inseparable part of this Director General of Tax Circular. In the NPWP registration, the KPP also requires the signatory to be the director/commissioner/attorney who, according to the Regulation of the Minister of Finance of the Republic of Indonesia Number 229 / PMK.03 / 2014 , is a tax consultant or employee of the company who has a brevet certificate (Supraba \& Bandiyono, 2017). The KPP assessment of this component might be seen from how the application of existing regulations, not focused on innovation what the KPP has done. Organizations at the KPP level are tasked with carrying out what is already in the regulations, although it does not rule out the possibility of innovation following the circumstances each KPP (Bandiyono \& Indrianto, 2019).

d. Human Resources.

This component relates to employee professionalism which includes attitudes and behaviors, skills, sensitivity, and discipline. Assessment indicators for this component include:

1) Have the code of conduct been fully implemented?

2) Do the employees help each other in getting work done?

3) Is there good coordination between the sections?

4) How many times is In House Training (IHT) done in one month?

5) In the past three months, has the Head of Office ever conducted IHT?

6) Has there been outbound training in the past year?

7) In the past month, has the Head of the Services Section overseen service quality?

The number of staff at KPP Pratama Jakarta Kelapa Gading is 92 people and most are in the age range of 31-35 years. There are 13 employees in the Services Section. In carrying out their duties they cooperate for the sake of the implementation of synergy in the Service Section. In terms of behavior, skills, sensitivity, and discipline have been discussed in subchapter 1 and have been supported by the results of questionnaire data processing from taxpayers. In terms of quality control, held at least once a month review is, especially in the Service Section to talk about what work has been done and discuss what would be done next. Besides review, there are rewards and punishments as a means of evaluating employees in carrying out their work. At KPP Pratama Jakarta Kelapa Gading, each month a held In House Training is to provide employees with new knowledge and skills guidelines. The In House Training conducted usually discusses what is being discussed in the DGT environment (SPT report problem, wealth report problem) and self-improvement.

e. Facilities and infrastructure.

This component relates to the availability and use of service facilities and infrastructure. The assessment indicators for this component include:

1) Is the TPT comfortable enough for tax officers or taxpayers (WP)?

2) Are the facilities and infrastructure available and ready at any time?

3) Have the facilities and infrastructure been used optimally?

4) Are there suggestion boxes and survey boxes along with supporting equipment in the form of paper and pens for writing? 
5) Is there a restricted area/ separation of access for workspace security? And has it been optimized for use?

Details about the various facilities available at the Jakarta Kelapa Gading KPP service are in Appendix II. In the Service Section, the facilities are deemed adequate under the standards stated in the Director-General of Tax Circular Letter Number SE - 09 / PJ / 2013. Facilities that have not been used to the maximum are suggestion boxes and taxpayer's satisfaction boxes (Bandiyono \& Al Hazmi, 2017). The boxes look empty like no one has ever used them and they are also not equipped with pens and paper near the boxes. Another facility that is quite crucial for the Services Section is the archive room. An archive space is a space where taxpayer documents are stored. Over time the growth of taxpayers is increasing. Even though the procurement is quite complicated, because of the limited space available in this office.

f. The handling of complaints.

This component is related to the concern of leaders and employees to anticipate the complaints and complaints of taxpayers, especially towards service satisfaction. The assessment indicators for this component include:

1) Is there a system that handles taxpayer complaints and complaints?

2) Is the system for handling complaints and complaints of taxpayers going well and following applicable regulations?

Complaints are submitted by the Taxpayer through the Directorate General of Taxes' complaints channel. The complaints channel includes telephone (tax ID), facsimile, email, website, and letter. (Bandiyono \& Septiana, 2018). Existing complaints are collected and then forwarded to the relevant KPP. In this KPP, every complaint is immediately forwarded to the relevant section or section. After that, a discussion was carried out by the internal section on how to proceed. In the Service Section complaints that occur are related to the telephone that was not picked up by employees and queue problems that accumulate at certain times. After tracing the phone that was complained of was indeed experiencing interference so it could not function properly. Regarding the long queues, the KPP admitted that this was a decrease in service quality. That happened because of the lack of human resources assigned especially in the Integrated Service Area (TPT) because two officers were undergoing training. Efforts made at the Service Section during crowded conditions are to maximize the counters in the TPT with existing resources including those who work in the back office. All employees focus on completing work rather than job responsibilities. Another thing is done at the end of the annual SPT reporting, long queues that occur are served until the evening even by implementing a strategy. In front of the office, 10 teams were formed, each consisting of 10 people from Service Section employees and other sections because this was a joint celebration at KPP Pratama Jakarta Kelapa Gading.

\section{CONCLUSION AND SUGESTION}

Based on the data and facts obtained and the discussion that has been described in the previous chapter regarding the implementation of the KPP Pratama Jakarta Kelapa Gading service as a Pilot KPP, some conclusions can be drawn as follows:

1. The true meaning of service is the provision of customer satisfaction. Services in the field of taxation are organized to meet the satisfaction of taxpayers when fulfilling their tax obligations. To realize this in the scope of the Directorate General of Taxes, circulars have been issued regarding the implementation of excellent services that are expected to provide satisfaction to taxpayers. The implementation of services at Jakarta Kelapa Gading KPP has largely been under the Circular of the Director-General of Taxes Number SE - 84 / 
PJ / 2011 regarding excellent service and SE - 09 / PJ / 2013 regarding guidelines for excellent service.

a. If we look at the service standard in the form of a service schedule and the schedule of officers has been carried out according to existing regulations. The attitude and behavior of officers in providing services reflect what KPP employees should do according to the circular.

b. Several indicators were assessed by taxpayers through a questionnaire from 25 respondents, namely service procedures at the Tax Office were considered quite easy (56\% of the votes), service officers have a sufficient level of discipline (64\% of the votes), officers had responsibility for providing services ( $84 \%$ of votes), officers have adequate ability (72\% of votes), the level of speed at completion of services is considered not fast (48\% of votes), officers have been polite and friendly when serving Taxpayers (76\% of votes) and an assessment of the atmosphere of the Tax Office felt comfortable by WP (60\% of the votes) because it was supported by the completeness of the existing facilities in the office. The results of this assessment reflect on how the advantages and disadvantages of KPP services. Therefore some WP opinions regarding the lack of services need to be taken seriously so that later the quality of service will be better and better. This aims to increase the trust and comfort of taxpayers so that they will be more enthusiastic in fulfilling their tax obligations.

2. The implementation of excellent service is an obligation of the KPP as a public service provider. To carry out performance evaluations and give awards to offices that have performed excellent service according to existing regulations, an assessment was held to obtain a pilot KPP title held by the Ministry of Finance Assessment Team. This assessment is regulated in Decree of the Minister of Finance of the Republic of Indonesia Number 128 / KMK.01 / 2013 concerning Guidelines for Evaluation of Pilot Service Offices in the Ministry of Finance and Decree of the Director-General of Tax Number KEP-161 / PJ / 2015 concerning Guidelines for Evaluation of Pilot Services Offices at Regional Office Level Directorate General of Taxes. Jakarta Kelapa Gading KPP is the first KPP Pilot Model in the North Jakarta area. Therefore following the implementation of existing services so that the KPP can get a pilot KPP title.

a.In terms of vision, mission, and service motto, KPP employees have implemented it following DGT's vision and mission and made it as their motivation in working. This is important because in one organization there must be a unifying step in their work.

b. Service standards and service announcements are measures of the quality of existing services. With the implementation of good service standards, the quality of service will be good too.

c.In terms of systems, mechanisms, and procedures, one of the advantages of the KPP is the detailed application of all existing SOPs which are not necessarily applied in other KPPs. The application of this SOP was accompanied by innovations carried out by KPP to support the implementation of its services.

d. In terms of human resources, standards of behavior and ethics have been applied in this office. Every month carried out review is to guarantee the quality of service and carried out IHT is to develop existing human resources.

e.In terms of facilities and infrastructure, facilities in this office are quite complete and adequate and are following what is standard in SE - 09 / PJ / 2013. Maybe what still needs to 
be considered is the use of suggestion boxes and satisfaction boxes that have not been optimal and crucial infrastructure such as archive space.

f. In terms of complaint handling, this KPP has used an integrated system in the Directorate General of Taxes. Complaints that occur will be submitted to each of the related parties to be studied and find solutions to the problem. As a public service provider, KPP Pratama Jakarta Kelapa Gading is concerned with criticism and suggestions from taxpayers.

Based on the assessment of several components, the authors argue that KPP Pratama Jakarta Kelapa Gading is suitable and has the right to assume the role of KPP Pilot.

\section{REFERENCE}

Asriyani, R., \& Bandiyono, A. (2019). Complexity Of Annual License Notification Of SmallMedium Tax Business Taxes. Jurnal Akuntansi, 23(2), 316-332.

Bandiyono, A., \& Indrianto, N.P.P. (2019). E-REKON LK APPLICATION AS A FORM OF ACCOUNTING AND E-GOVERNMENT INFORMATION SYSTEMS IMPLEMENTATION IN INDONESIA. International Journal of Innovation, Creativity and Change, 8(3), 23-40.

Bandiyono, A., \& Aryani, S. D. (2019). EVALUATION OF SERVICE STANDARDS IN THE INFORMATION AND COMPLIANCE SERVICE TAX OFFICE. Dinasti International Journal of Education Management And Social Science, 1(1), 55-66.

Bandiyono, A., \& Pratama, L. W. (2019). RISK CULTURAL EVALUATION AS ORGANIZATIONAL CULTURE IN THE TAX SERVICE OFFICE. Dinasti International Journal of Management Science, 1(2), 133-147.

Bandiyono, A., \& Murwaningsari, E. (2019). Effect of Intra Group Transaction, Thin Capitalization and Executive Characters on Tax Avoidation with Multinationality as a Moderation. Journal of Accounting, Business and Finance Research, 7(2), 82-97.

Bandiyono, A., \& Augustine, Y. (2019). Organizational Performance As A Mediation On The Effect Of Levers Of Control And Learning Organization On Tax Compliance. International Journal of Business, Economics and Law-IJBEL.

Bandiyono, A., \& Sadry, D. A. P. (2018). PENERAPAN PERATURAN PEMERINTAH NOMOR 46 TAHUN 2013 TERHADAP USAHA MIKRO KECIL DAN MENENGAH (UMKM). Jurnal Aplikasi Bisnis, 8(2).

Bandiyono, A. (2018). PENGARUH BELANJA PEMERINTAH DAERAH BERDASARKAN FUNGSI TERHADAP PENINGKATAN IPM DAN PENGENTASAN KEMISKINAN (STUDI PADA KABUPATEN/KOTA DI PROVINSI ACEH). INFO ARTHA, 2(1), 11-28.

Bandiyono, A., \& Ustadnia, M. (2018). MEKANISME PENGADAAN BARANG OPERASIONAL DENGAN METODE PENGADAAN LANGSUNG. Jurnal Aplikasi Bisnis, 8(2).

Bandiyono, A. (2017). PROSES BISNIS SEKSI PENGAWASAN DAN KONSULTASI I DI KANTOR PELAYANAN PAJAK PENANAMAN MODAL ASING. Jurnal Aplikasi Bisnis, 8(1), 75-80.

Bandiyono, A. (2017). TINJAUAN PELAYANAN PELAPORAN SPT MASA PPN. Jurnal Aplikasi Bisnis, 7(2), 29-34. 
Bandiyono, A., \& Akhmadi, A. How are the Annual Supervision Work Programs in the Local Government Inspectorate?(Evidence from Indonesia).

Bandiyono, A., \& Rahmawati, D. EVALUASI PELAKSANAAN TUGAS DAN FUNGSI KANTOR PELAYANAN PAJAK DALAM PENGOLAHAN SURAT. Jurnal Kebijakan Publik, 9(2), 79-88.

Bandiyono, A., \& Septiana, B. F. PELAKSANAAN E-BILLING PAJAK PADA KANTOR PELAYANAN PAJAK. Jurnal Kebijakan Publik, 9(1), 19-26.

Bandiyono, A., \& Ahmad, L. C. A. EVALUASI TATA CARA PELAPORAN USAHA KENA PAJAK MELALUI APLIKASI E-REGISTRATION. Jurnal Demokrasi Dan Otonomi Daerah, 15(1), 47-54.

Bandiyono, A., \& Simbolon, D. J. TINJAUAN SYARAT KEADILAN VERTIKAL DAN HORIZONTAL WAJIB PAJAK. Jurnal Demokrasi Dan Otonomi Daerah, 17(1), 1924.

Bandiyono, A., \& Chaerul, I. F. A. LAYANAN PENYELESAIAN PERMOHONAN PENDAFTARAN NPWP MELALUI APLIKASI REGISTRASI ELETRONIK (EREGISTRATION). Jurnal Demokrasi Dan Otonomi Daerah, 17(2), 137-144.

Bandiyono, A. BENTUK PUSAT INVESTASI PEMERINTAH SEBAGAI BADAN LAYANAN UMUM. JURNAL FESTIVA, 1(2), 49-56.

Bandiyono, A., \& Nugraha, A. Y. PELAYANAN PRIMA KEPADA WAJIB PAJAK. Jurnal Demokrasi Dan Otonomi Daerah, 16(2), 101-108.

Bandiyono, A. TATA CARA PEMERIKSAAN PAJAK PADA SEKSI PEMERINKSAAN. Jurnal Demokrasi Dan Otonomi Daerah, 15(3).

Bandiyono, A., \& Al Hazmi, R. KUALITAS PELAYANAN INSTITUSI, INFRASTRUKTUR, KESEHATAN DAN PENDIDIKAN, SERTA KEPATUHAN PAJAK. Jurnal Kebijakan Publik, 7(1).

Bandiyono, A., \& Andiani, S. TINJAUAN PENGADAAN PERANGKAT PENGOLAH DATA DAN KOMUNIKASI. Jurnal Kebijakan Publik, 10(1), 47-52.

Bandiyono, A., \& Al Fajar, M. Z. EVALUASI PELAYANANWAJIB PAJAK DALAMAKTIVASIE-FIN. Jurnal Kebijakan Publik, 10(1), 17-24.

Bandiyono, A. TRANSFER DANA SEBAGAI BENTUK DESENTRALISASI FISKAL BAGI PEMERINTAH DAERAH. Jurnal Demokrasi Dan Otonomi Daerah, 15(2), 103-108.

Bandiyono, A. PENERAPAN PELAYANAN PUBLIK DI KANTOR PELAYANAN PAJAK. Jurnal Demokrasi Dan Otonomi Daerah, 16(1), 19-24.

Bandiyono, A., \& Andri, S. (2012). Evaluasi Program Pelatihan Bendahara Pengeluaran Pegawai Kementerian Keuangan. Jurnal Administrasi Pembangunan, 1(01).

Supraba, R. M., \& Bandiyono, A. Penerapan E-Procurement Dalam Proses Penggadaan Barang Dan Jasa. Jurnal Demokrasi Dan Otonomi Daerah, 14(3), 229-236.

Republik Indonesia. 2009. Undang-Undang Nomor 25 Tahun 2009 tentang Pelayanan Publik. 
Kementerian Keuangan Republik Indonesia. 2009. Peraturan Menteri Keuangan Republik Indonesia Nomor 62 Tahun 2009 tentang Organisasi dan Tata Kerja Instansi Vertikal Direktorat Jenderal Pajak 